\section{Methotrexate Has No Antifibrotic Effect in Bleomycin-induced Experimental Scleroderma}

\section{To the Editor:}

Scleroderma is a chronic inflammatory disease that is characterized by widespread microvascular damage and excessive deposition of collagen in the skin and internal organs, although its pathogenesis is not fully understood. Opinions regarding the current treatment of scleroderma are based on recently developed European League Against Rheumatism/EULAR Scleroderma Trials and Research Group recommendations. However, no disease-modifying drugs are currently available that can modify the course of the disease. In systemic sclerosis, methotrexate (MTX) has been studied in controlled trials, with controversial outcomes ${ }^{1,2}$. We evaluated the possible effectiveness of MTX in a bleomycin (BLM)-induced experimental scleroderma model ${ }^{3,4}$

Our study included 3 groups of mice $(n=10 \mathrm{Balb} / \mathrm{c}$ mice in each group). Control group mice were only administered $100 \mu 1$ of phosphate-buffered saline (PBS), while mice in the other 2 groups were subcutaneously administered BLM (100 $\mu \mathrm{g} /$ day, dissolved in $100 \mu 1 \mathrm{PBS})$ for 4 weeks. In addition to BLM, the mice in the third group were administered MTX intraperitoneally ( $1 \mathrm{mg} / \mathrm{kg} /$ week).

At the end of the fourth week, all mice were sacrificed and blood and tissue samples were harvested. Interleukin 2 (IL-2), IL-4, and transforming growth factor $B 1$ serum levels, tissue hydroxyproline contents, dermal thicknesses, and the number of $\alpha$-smooth muscle actin-positive ( $\alpha$-SMA+) cells were determined. The Kruskal-Wallis 1-way analysis of variance and Mann-Whitney U tests were used.

Histological evaluation revealed that subcutaneous BLM administration markedly increased dermal thickness $(\mathrm{p}<0.001)$, subcutaneous eosinophilic infiltration ( $\mathrm{p}<0.05)$, and expression of $\alpha$-SMA $(\mathrm{p}<0.001)$, and the hydroxyproline content of the skin showed an increase of up to about 3-fold following BLM administration compared with the PBS-treated mice $(p<0.001)$. MTX treatment did not change the tissue hydroxyproline content, dermal thickness (Figure 1), inflammatory cell infiltration, or number of $\alpha$-SMA+ cells (Table 1 ).

Controversial results of MTX treatment have been reported in patients with scleroderma ${ }^{1,2}$. MTX is reported to be more effective than placebo according to predefined response criteria, although it does not significantly improve total skin score, extension indexes, grip strengths, oral opening, visual analog scale of patient's general well-being, and organ involvement ${ }^{1}$. Moreover, a subsequent study ${ }^{2}$ demonstrated the ineffectiveness of MTX. Our study also supports the ineffectiveness of MTX.

A number of antiinflammatory effects exerted by MTX seem to be related to endogenous adenosine increase ${ }^{5}$. However, stimulation of the adenosine $A_{2 A}$ receptor dramatically increases collagen production from dermal fibroblasts, and suppresses the expression and activity of matrix metalloproteinases ${ }^{6}$. Moreover, blockade of the adenosine $\mathrm{A}_{2 \mathrm{~A}}$ receptor is reported to prevent BLM-induced dermal fibrosis ${ }^{6}$. In addition, MTX is reported to increase synthesis of glycosaminoglycans in scleroderma and normal fibroblast cultures ${ }^{7}$. Therefore, it could not be expected that MTX may exert antifibrotic effects.

Increased levels of Th2-type cytokines, which stimulate the synthesis of collagen by fibroblasts ${ }^{8}$, have been reported in scleroderma ${ }^{9}$. However, MTX modulates the immune status toward Th 2 dominance ${ }^{10}$. The possible effect of MTX on Th2 cytokines may have led to its lack of antifibrotic effect in our study.

The results of our study demonstrate that MTX had no antifibrotic effect in the experimentally induced dermal fibrosis/sclerosis model.

METIN OZGEN, MD, Rheumatology Fellow; SULEYMAN S. KOCA, MD, Associate Professor; AHMET ISIK, MD, Professor, Department of Rheumatology; IBRAHIM H. OZERCAN, MD, Professor, Departments of Pathology, Faculty of Medicine, Firat University, Elazig, Turkey.
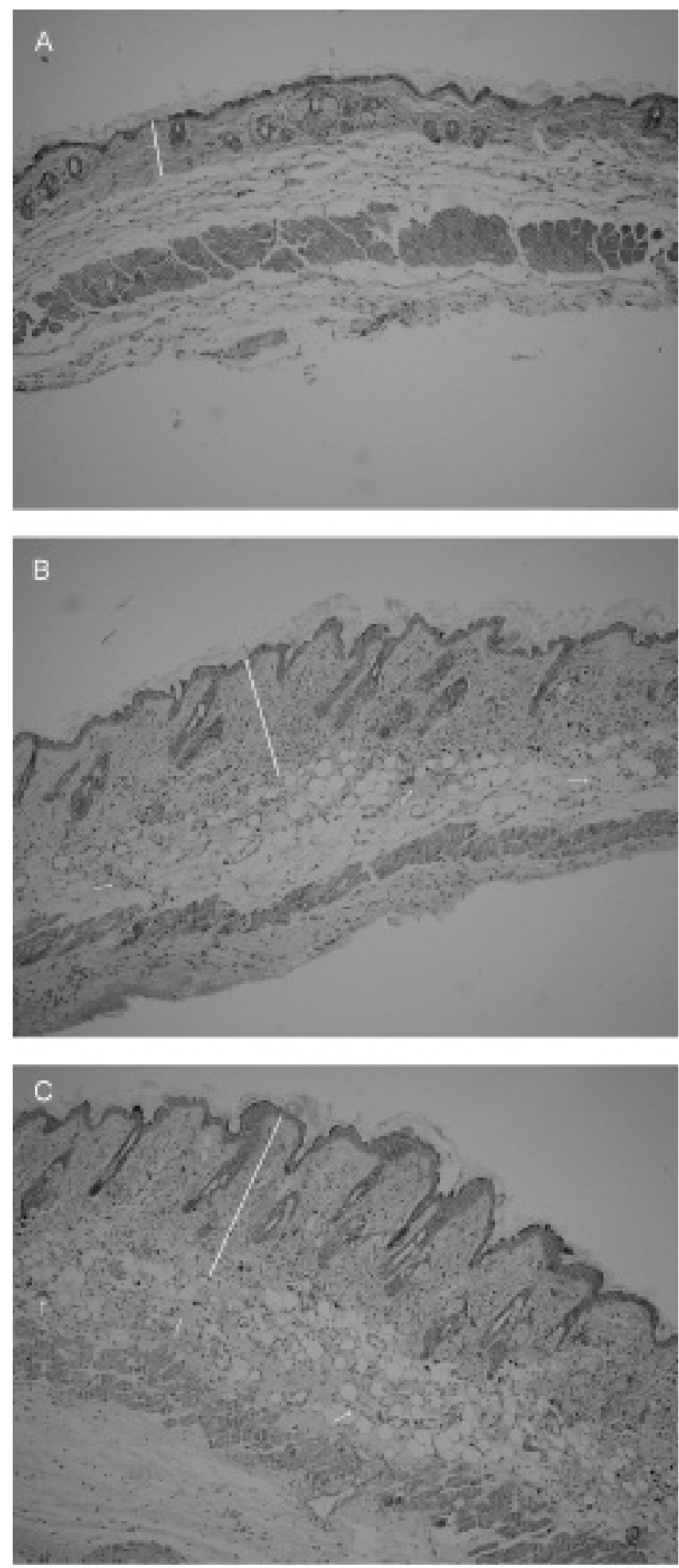

Figure 1. Histopathological evaluation of skin sections of Balb/c mice (H\&E stain, original magnification x100). A. The histopathological appearances of mice administered phosphate-buffered saline were normal B. Mice treated with bleomycin demonstrated definite dermal sclerosis with thickened collagen bundles in the thickened dermis. C. Mice treated with bleomycin plus methotrexate did not show any significant improvements. 
Table 1. Serum cytokines, tissue hydroxyproline levels, and histopathological findings in Balb/c mice groups.

\begin{tabular}{lccc}
\hline Characteristics & Control & Bleomycin & $\begin{array}{c}\text { Bleomycin + } \\
\text { Methotrexate }\end{array}$ \\
\hline IL-2, pg/ml & $7.53 \pm 0.45$ & $8.44 \pm 2.82$ & $8.66 \pm 2.99$ \\
IL-4, pg/ml & $7.04 \pm 0.13$ & $8.43 \pm 2.90$ & $8.13 \pm 2.66$ \\
TGF-B1, pg/ml & $1098.4 \pm 486.2$ & $1363.6 \pm 487.2$ & $1257.8 \pm 421.4$ \\
$\begin{array}{l}\text { Tissue hydroxyproline, } \\
\text { mg/g dry tissue }\end{array}$ & $0.52 \pm 0.19$ & $1.71 \pm 0.58^{*}$ & $1.51 \pm 0.65^{*}$ \\
$\begin{array}{l}\text { Dermal thickness, } \mu \mathrm{m} \\
\text { Dermal tissue, }\end{array}$ & $192.8 \pm 53.5$ & $435.5 \pm 77.8^{*}$ & $466.6 \pm 192.2^{*}$ \\
$\quad \begin{array}{l}\text { eosinophil/HPF } \\
\text { Subcutaneous tissue, } \\
\quad \text { eosinophil/HPF }\end{array}$ & $9.9 \pm 9.4$ & $9.80 \pm 5.1$ & $13.6 \pm 7.2$ \\
$\alpha-$ SMA, cells/HPF & $1.02 \pm 0.3$ & $19.4 \pm 15.5^{* *}$ & $19.3 \pm 8.9^{* *}$ \\
\hline
\end{tabular}

$\alpha$-SMA: $\alpha$-smooth muscle actin; HPF: high-power field $(\times 400)$; IL: interleukin; TGF: transforming growth factor. ${ }^{* *} \mathrm{p}<0.05, * \mathrm{p}<0.001 \mathrm{com}-$ pared to the control group.

Address correspondence to Dr.S. Koca; E-mail: kocassk@yahoo.com This study was supported by the Society for Research and Education in Rheumatology of Turkey.

\section{REFERENCES}

1. van den Hoogen FH, Boerbooms AM, Swaak AJ, Rasker JJ, van Lier HJ, van de Putte LB. Comparison of methotrexate with placebo in the treatment of systemic sclerosis: a 24 week randomized double-blind trial, followed by a 24 week observational trial. Br J Rheumatol 1996;35:364-72.

2. Pope JE, Bellamy N, Seibold JR, Baron M, Ellman M, Carette S, et al. A randomized, controlled trial of methotrexate versus placebo in early diffuse scleroderma. Arthritis Rheum 2001;44:1351-8.
3. Yamamoto T, Takagawa S, Katayama I, Yamazaki K, Hamazaki Y, Shinkai H, et al. Animal model of sclerotic skin. I: Local injections of bleomycin induce sclerotic skin mimicking scleroderma. J Invest Dermatol 1999;112:456-62.

4. Yamamoto T, Takagawa S, Katayama I, Nishioka K. Anti-sclerotic effect of transforming growth factor-beta antibody in a mouse model of bleomycin-induced scleroderma. Clin Immunol 1999;92:6-13.

5. Baggott JE, Vaughn WH, Hudson BB. Inhibition of 5-aminoimidazole-4-carboxamide ribotide transformylase, adenosine deaminase and 5 '-adenylate deaminase by polyglutamates of methotrexate and oxidized folates and by 5-aminoimidazole-4-carboxamide riboside and ribotide. Biochem J 1986;236:193-200.

6. Chan ES, Fernandez P, Merchant AA, Montesinos MC, Trzaska S, Desai A, et al. Adenosine A2A receptors in diffuse dermal fibrosis: pathogenic role in human dermal fibroblasts and in a murine model of scleroderma. Arthritis Rheum 2006;54:2632-42.

7. van den Hoogen FH, van der Kraan PM, Boerbooms AM, van den Berg WB, van Lier HJ, van de Putte LB. Effects of methotrexate on glycosaminoglycan production by scleroderma fibroblasts in culture. Ann Rheum Dis 1993;52:758-61.

8. Wynn TA. Fibrotic disease and the $\mathrm{T}(\mathrm{H}) 1 / \mathrm{T}(\mathrm{H}) 2$ paradigm. Nat Rev Immunol 2004;4:583-94.

9. Needleman BW, Wigley FM, Stair RW. Interleukin-1, interleukin-2, interleukin-4, interleukin-6, tumor necrosis factor alpha, and interferon-gamma levels in sera from patients with scleroderma. Arthritis Rheum 1992;35:67-72.

10. Herman S, Zurgil N, Langevitz P, Ehrenfeld M, Deutsch M. Methotrexate selectively modulates TH1/TH2 balance in active rheumatoid arthritis patients. Clin Exp Rheumatol 2008;26:317-23.

J Rheumatol 2010;37:3; doi:10.3899/jrheum.090961 